\title{
ANALISIS FAKTOR-FAKTOR YANG MEMPENGARUHI MINAT MAHASISWA AKUNTANSI DALAM PENGAMBILAN SERTIFIKASI AKUNTANSI
}

\author{
Harum Uswatu Chasanah, Maria Yovita R Pandin \\ harumuswatunhasanah123@gmail.com, yovita_87@untag-sby.ac.id
}

\begin{abstract}
The purpose of this study was to analyze the factors that influence the interest of accounting students to take accounting certification. The factors for taking accounting certification are measured by the variables of intention, motivation, financial rewards, CA. The data used in this study is primary data, namely the collection technique by distributing online questionnaires to accounting students at Adi Buana University Surabaya. The results showed that the variables of intention, motivation, CA, had a significant effect on the interest of accounting students at Adi Buana University in choosing a career as a public accounting profession. Financial rewards moderate the effect of motivation, intention on the interest of accounting students in choosing a career as a public accounting profession. However, it cannot moderate the perceived effect of professional training on the interest of accounting students in choosing a career as a public accounting profession.
\end{abstract}

Keywords: Intention, Motivation, Perception, Financial Award, CA

\begin{abstract}
ABSTRAK
Tujuan dari penelitian ini adalah untuk menganalisis faktor-faktor yang mempengaruhi minat mahasiswa akuntansi terhadap pengambilan sertifikasi akuntansi. Faktor-faktor pengambilan sertifikasi akuntansi diukur dengan variabel niat, motivasi, penghargaan finansial, CA. Data yang digunakan pada penelitian ini adalah data primer yaitu dengan teknik pengumpulan dengan menyebarkan kuesioner online pada mahasiswa akuntansi di Universitas Adi Buana Surabaya. Hasil penelitian menunjukkan variabel niat, motivasi, CA, yang berpengaruh signifikan terhadap minat mahasiswa akuntansi di Universitas Adi Buana dalam pemilihan karir sebagai profesi akuntan publik. Penghargaan finansial memoderasi pengaruh motivasi, niat terhadap minat mahasiswa akuntansi dalam pemilihan karir sebagai profesi akuntan publik. Tetapi tidak dapat memoderasi pengaruh presepsi pelatihan profesional terhadap minat mahasiswa akuntansi dalam pemilihan karir sebagai profesi akuntan publik.
\end{abstract}

Kata kunci: Niat,Motivasi,Presepsi,Penghargaan finansial ,CA 


\section{PENDAHULUAN}

Salah satu aspek penting mahasiswa saat menjelang kelulusannya adalah kemana minat atau keinginan kemana para lulusan sarjana akan menjalankan tujuan hidup. Seperti halnya dalam mencari pekerjaan sesuai dengan studi yang mereka pilih atau melanjutkan pendidikan yang lebih tinggi. Karena ketetapan dalam pemilihan karir menjadi titik penting dalam perjalanan hidup manusia, oleh karena itu karir berkontribusi besar bagi diri dan merupakan nilai dasar dan tujuan hidup seseorang. Salah satunya pada lulusan Fakultas Ekonomi atau pada program akuntansi pemilihan karir tidak tertutup pada profesi akuntansi saja, banyak pilihan profesi yang dapat dijalani oleh mereka tergantung faktor-faktor yang melatarbelakanginya.

Pilihan karir yang dapat diambil seseorang yang memiliki latar belakang pendidikan akuntansi antara lain sebagai akuntan publik, akuntan pemerintah, akuntan perusahaan, dan akuntan pendidik. Dari keempat pilihan karir tersebut yang membedakan adalah bidang tempat akuntan tersebut bekerja. Akuntan publik merupakan akuntan yang bekerja untuk kepentingan publik. Akuntan pemerintah merupakan akuntan yang bekerja dibagian pemerintah. Akuntan perusahaan merupakan akuntan yang bekerja disuatu perusahaan. Sedangkan akuntan pendidik adalah akuntan yang bekerja di bidang pendidikan sebagai pengajar.

Di era globalisasi sekarang, teknologi menjadi salah satu faktor utama unuk menacari informasi tentang perkembangan ilmu dan informasi seputar akuntansi yang dapat mudah diakses dimanapun. Menurut Enny \& Badingatus (2014) Sejak tanggal 31 Desember 2015 telah diresmikan Masyarakat Ekonomi ASEAN yang tidak hanya membuka arus perdagangan barang atau jasa, tetapi terbukanya pasar tenaga kerja profesional, salah satunya akuntansi. Profesionalisme dalam bidang akuntansi dapat diperoleh dengan sertifikasi akuntan yaitu: Chartered Accountant (CA) adalah kualifikasi sebagai akuntan profesional.

Saat ini indonesia masih sangat kekurangan akuntan profesional dibandingkan negara lain yang penduduknya jauh lebih sedikit dibandingkan di indonesia menurut data INKINDO(2016) di Thailand jumlah akuntan sebanyak 56,125 orang, Malaysia sebanyak 30,236 orang, Singapura sebanyak 27,394 orang, filipina sebanyak 19,573 orang, sedangkan di indonesia hanya 15,940 orang. Indonesia saat ini menghadapi MEA (Masyarakat Ekonomi ASEAN) dimana sistem perekonomiannya melibatkan kerja sama antara Negara-negara ASEAN, yang melibatkan pola perdagangan lebih bebas dan itu berimbas terhadap pada persaingan jasa akuntansi dan banyak akuntan dari berbagai negara ASEAN masuk ke indonesia. Oleh karena itu Indonesia sangat membutuhkan akuntan-akuntan muda profesional untuk bersaing dengan negara-negara lainnya.Hal tersebut disebabkan karena kurang minatnya mahasiswa yang telah lulus sarjana untuk berprofesi sebagai akuntan profesional. Minat merupakan suatu ketertarikan, ketika seseorang memiliki minat terhadap sesuatu mereka akan memerhatikan secara konsisten aktivitas tersebut dengan rasa senang, karena hal tersebut datang karena rasa suka bukan karena keterpaksaan dari siapapun.

Faktor yang mempengaruhi mahasiswa menjadi akuntan profesional adalah motivasi mahasiswa itu sendiri. Selain itu presepsi seseorang juga mempengaruhi pemikiran orang tersebut. Jika seseorang mempunyai presepsi positif maka akan cenderung mendukung hal tersebut, dan sebalikanya jika seseorang mempunyai presepsi negatif maka seseorang akan menghindari hal tersebut. Mahasiswa akuntansi mempunyai presepsi terhadap 
akuntan profesional bermacam-macam ada yang positif maupun negatif dan hal tersebut mempengaruhi seseorang untuk berprofesi menjadi akuntan profesional.

Dari beberapa penjelasan diatas maka peneliti ingin mengetahui tentang variabel niat, motivasi,presepsi, penghargaan finansial, CA terhadap seseorang yang mengambilsertifikasi akuntan.

\section{TINJAUAN PUSTAKA}

\section{A. Chartered Accountant (CA)}

Chartered Accountant adalah sebutan bagi kualifikasi akuntan profesional sesuai standar internasional. Kualifikasi ini dibangun dengan mengutamakan integritas dan profesionalisme bagi seorang akuntan di indonesia dalam menghadapi persaingan secara global. Eksitensi CA Indonesia sangat penting untuk membangun culture bisnis yang kuat, visioner, memegang teguh nilai-nilai, bertanggumg jawab, dan fokus terhadap nilai tambah positif bagi intitusinya. Sebagai wadah berhimpunnya akuntan seluruh indonesia, IAI berkiprah secara optimal untuk mewujudkan akuntan profesional terpecaya, berkualitas tinggi, serta bisa diandalkan oleh dunia. IAI memiliki dan komitmen untuk membantu setiap individu yang ingin sukses sebagai akuntan profesional.

Gelar CA diberikan untuk individu yang mampu melewati ujian Chartered Accountant dan memiliki pengalaman bekerja selama 3-4 tahun dibidang akuntans yang diperoleh dalam tujuh taun terakhir. Seorang CA juga dapat mendirikan atau menjadi partner kantor jasa akuntansi.Ikatan Akuntansi Indonesia (IAI) menyelenggarakan ujian CA dengan tujuan untuk mendapatkan Akuntan sebagai anggota utama IAI yang memiliki:

1. Kualifikasi untuk menjalankan peran sebagai Akuntan Profesional yang sesuai kompetensi utama dan kompetensi khusus CA.

2. Komitemen yang tinggi terhadap etika, nilai-nilai dan perilaku profesional.

3. Keahlian profesional untuk menjalankan peran tersebut.

B. Teori Perilaku Terencana Theory Planned Behavior (TPB)

Dengan menerapkan model Theory Planned Behavior (TPB) oleh Victor Vroom pada tahun 1964 dapat mengetahui faktor-faktor yang mempengaruhi niat mahasiswa. Teori ini merupakan perluasan dari Theory of Reasoned Actions yang dikembangkan oleh Icek Ajzen dan Martin Fishbein (1980 ). Ajzen \& Fishbein mengembangkan teori tersebut dengan konstruk yang belum ada di TRA yaitu teori persepsi kontrol perilaku (perceived behavioural control). ). Theory of Planned Behavior (TPB), menjelaskan tentang perilaku individu yang dipengaruhi oleh konsep pengendalian yang dimiliki oleh individu tersebut. Semakin baik konsep pengendalian individu yang dimiliki maka akan semakain baik pula individu tersebut berperilaku. TPB bertujuan untuk memprediksi dan memahami dampak niat berperilaku, mengidentifikasi strategi untuk mengubah perilaku serta menjelaskan perilaku nyata manusia. Dalam hubungan ini TPB diasumsikan bahwa manusia yang bersifat rasional akan menggunakan informasi yang ada secara sistematik kemudian mencari tahu dampak perilakunya sebelum memutuskan akan mewujudkan perilaku tersebut.

1. Kepercayaan perilaku (behavioral beliefs), yaitu kepercayaan tentang kemungkinan terjadinya perilaku.

2. Kepercayaan normatif (normatif beliefs),yaitu kepercayantentang ekspetasi normatif dari orang lain dan motivasi untuk menyetujui ekspetasi tersebut. 
3. Kepercayaan kontrol (control beliefs), yaitu kepercayaan tentang keberadaan faktorfaktor yag akan memfasilitasi atau merintangi kinerja dari perilaku dan kekuatan presepsi dari faktor-faktor tersebut.

Yudhantoko (2013) menjelaskan, seorang mahasiswa akuntansi tertarik pada suatu karir untuk dikejar di masa depan yang disebabkan karena karir tersebut dianggap memiliki suatu nilai yang memberikan kepuasaan pribadi. Dalam proses pemilihan karir, mahasiswa akuntansi akan membentuk perilaku atau usaha - usaha yang maksimal guna mendapatkan hasil yang diinginkannya.

\section{Teori Pengharapan}

Menurut Robbins Stephen (2008) motivasi (motivation) adalah proses yang menjelaskan intesitas, arah, dan ketekunan seorang individu utuk mencapai tujuannya. Menurut Robbins Stephen (2008) Teori harapan menujukkan kekuatan yang akan cenderung untuk bertindak dalam cara tertentu tergantung dari suatu harapan bahwa tindakan tersebut akan diikuti dengan hasil yag ada dan pada daya tarik dari hasil itu terhadap individu tersebut.

Inti dari teori pengharapan adalah pemahaman sasaran individu dan keterkaitan antara upaya dan kinerja, antara kinerja dan imbalan. Oleh karena itu, pemilihan karir seseorang mahasiswa akuntansi ditentukan pada pengharapan akan karir yang akan mereka pilih apakah karir tersebut dianggap mampu memenuhi kebutuhan individu mereka dan apakah karir tersebut mempunyai daya tarik untuk mereka. Misalnya apakah karir tersebut dapat memberikan imbalan organisasi yang layak seperti bonus, kenaikan penghargaan finansial gaji atau promosi, atau mahasiswa mempunyai pengharapan terhadap karir yang dipilihnya ini dapat memberikan apa yang mereka inginkan yang ditinjau dari faktor nilai intrinsik. Apakah sesuai dengan harapan untuk mencapai karir yang akan ia pilih.

Teori harapan berfokus pada tiga hubungan Robbins Stephen (2008) :

1. Hubungan usaha-kinerja, perasaan individu yang mengeluarakan sejumlah usaha akan menghasilkan kinerja.

2. Hubungan kinerja-penghargaan, suatu tingkat dimana individu yakin bahwa bekerja pada tingkat tertentu akan mencapai pencapaian sesuai yang diinginkan.

3. Hubungan penghargaab tujuan-tujuan pribadi, dimana penghargaan-penghargaan organisasi memuaskan tujuan-tujuan pribadi.

D. Pengertian Niat

Niat adalah dorongan yang timbul secara sadar atau tidak sadar untuk melakukan sesuatu tindakan untuk tujuan tertentu, niat yang baik akan mendorong pada hal yang baik pula. Menurut Jogiyanto (2007) niat tidak selalu statis dan dapat berubah seiring berjalannya waktu, dapat disimpulkan semakin panjang interval waktu maka akan semakin besar kemungkinan niat seseorang berubah. Niat seseorang untuk melakukan sesuatu dipengaruhi beberapa faktor-faktor, yaitu:

1. Sikap (attitude), menurut Jogiyanto (2007) adalah evaluasi kepercayaan atau perasaan negatif maupun positif dari seseorang jika melakukan perilaku yang ditentukan. Selain itu menurut Hidayat (2010), sikap diartikan sebagai perasaan mendukung atau 
memihak terhadap suatu objek yang akan disikapi tersebut. Berdasarkan penelitian yang dilakukan Sumaryono (2016) sikap pada CA berpengaruh positif dan signifikan terhadap niat mahasiswa untuk mengambil sertifikasi CA.

2. Norma Subjektif adalah pandangan atau persepsi individu mengenai kepercayaankepercayaan orang lain yang bisa mempengaruhi keinginan atau niat untuk melakukan sesuatu atau tidak melakukan sesuatu (Jogiyanto 2007). Norma Subjektif mempunyai fungsi berdasarkan fungsi normative beliefs, yang merupakan harapan atau keyakinan terhadap kesetujuan atau ketidaksetujuan seorang individu ataupun kelompok yang mempunyai peran penting terhadap suatu tingkah laku. Menurut Ajzen faktor pendukung yang paling berpengaruh itu berasal dari orang tua, saudara, teman, pasangan, dan keluarga.

Ada dua komponen yang mempengaruhi norma subjektif:

a. Motivation to Comply merupakan suatu cara untuk memotivasi diri sendiri dalam memperjuangkan suatu keinginan tersebut.

b. Normative Beliefs, merupakan suatu keyakinan atau pemikiran yang dimiliki oleh seorang individu terhadap keinginan orang lain untuk mengacu keiinginan yang berada dalam diri dalam melakukan suatu kegiatan tingkah laku yang diingikan atau tidak melakukannya.

E. Motivasi

Menurut Samsudin (2010) motivasi merupakan suatu proses yang mempengaruhi atau mendorong dari luar terhadap individu atau kelompok kerja agar mereka berminat melaksankan sesuatu yang telah ditetapkan. Sedangkan menurut Liang Gie dalam Samsudin menyatakan motivasi merupakn suatu pekerjaan yang dilakukan oleh manajer dalam memberikan inspirasi ,semangat srta dorongan kepada orang lain.

Motivasi Menurut Mulyasa (2003) merupakan tenaga pendorong atau penarik yang menyebabkan adanya tingkah laku ke arah suatu tujuan tertentu. Seseorang akan bersunguhsunguh karena memiliki motivasi yang tinggi terhadap tujuannya.

Berikut beberapa faktor yang mempengaruhi motivasi
a. Promosi
b. Prestasi kerja
c. Pekerjaan itu sendiri
d. Penghargaan
e. Tanggung jawab
f. Pengakuan
g. Keberhasilan dalam bekerja

F. Pengharagaan Finansial

Pengahargaan Finansial merupakan salah faktor yang memepengaruhi pertimbangan mahasiswa akuntansi dalam memilih profesinya. Semakin tinggi penghargaan finansial semakin tinggi pula minat mahasiwa dalam memilih profesi tersebut. Selain itu akuntan merupakan salah satu profesi yang menghasilakan penghasilan yang relatif cukup besar dibandingkan dengan profesi lainnya. Bagi individu pekerjaan yang dilakukan bukan hanya sekedar memenuhi kebutuhan ekonomi saja, melainkan faktor ekonomi.

Veithzal Rivai (2012) menjelaskan tujuan pemberian penghargaan finansial adalah sebagai berikut:

1. Menjalin ikatan kerjasama antara pemilik usaha dengan karyawan.

2. Memenuhi kebutuhan-kebutuhan fisik dan status sosial karyawan, agar karyawan memperoleh kepuasan kerja.

3. Mempermudah pengadaan karyawan yang berkualitas bagi perusahaan.

4. Memotivasi karyawan untuk bekerja dengan baik. 
5. Mencegah turnover karyawan yang tinggi, agar stabilitas karyawan lebih terjamin.

6. Membuat karyawan semakin disiplin bekerja.

7. Penghargaan finansial yang baik menghindarkan pengaruh karyawan dari serikat pekerja, sehingga karyawan akan berkonsentrasi pada pekerjaannya.

8. Mencegah karyawan berpindah ke perusahaan lainnya.

9. Jika penghargaan finansial diberikan sesuai dengan undang- undang yang berlaku seperti batas upah minimum, maka intervensi pemerintah dapat dihindarkan.

\section{G. Persepsi}

Persepsi adalah proses terhadap individu yang dapat mngenali objek atau fakta objektif dengan menggunakan alat individu (Zamroni,2013). Persepsi seseorang tidak dapat berdiri sendiri melainkan adanya faktor-faktor yang mempengaruhi persepsi tersebut. Hal inilah yang menyebabkan interpretasi sesorang berbeda-beda meskipun apa yang dilihatnya sama. Ada 4 faktor yang mempengaruhi persepsi seseorang.

1. Motif merupakan faktor internal yang dapat merangsang perhatian yang dapat menyebabkan munculnya keinginan individu melakuakan sesuatu.

2. Kesediaan dan harapan menentukan mana yang akan dipilih untuk di terima selanjutnya bagaimana pesan yang dipilih itu akan ditata dan di interprestasi.

3. Intensitas Rangsangan Kuat lemahnya rangsangan yang diterima berpengaruh bagi individu.

4. Pengulangan Suatu rangsangan yang muncul atau terjadi secara berulang-ulang yang akan menarik perhatian sebelum mencapai titik jenuh.

Faktor Eksternal yang mempengaruhi persepsi, merupakan karakteristik dari lingkungan dan obyek-obyek yang terlihat didalamnya. Elemen-elemen tersebut dapat mengubah sudut pandang seseorang terhadap dunia sekitarnya dan mempengaruhi bagaimana seseorang merasakannya atau menerimanya. Sementara itu faktor-faktor eksternal yang mempengaruhi persepsi adalah:

A. Ukuran dan Penempatan Dari Obyek atau Stimulus Faktor ini menyatakan bahwa semakin besarnya hubungan suatu obyek, maka semakin mudah dipahami. Bentuk ini akan mempengaruhi persepsi seseorang dan dengan melihat bentuk ukuran suatu obyek individu akan mudah untuk perhatian pada gilirannya membentuk persepsi.

B. Warna dari Obyek-obyek yang mempengaruhi cahaya lebih banyak, akan lebih mudah dipahami (to be perceived) dibandingkan dengan yang sedikit.

C. Keunikan dan Kekontrasan Stimulus.

Stimulus luar yang penampilannya dengan latar belakang dan sekelilingnya yang sama sekali diluar dugaan individu yang lain akan banyak menarik perhatian.

D. Intensitas dan Kekuatan dari Stimulus.

Stimulus dari luar akan memberi makna lebih sering diperhatikan dibandingkan dengan yang hanya sekali dilihat. Kekuatan dari stimulus merupakan daya dari suatu obyek yang bisa mempengaruhi persepsi.

E. Motion atau Gerakan Individu akan banyak memberikan perhatian terhadap obyek yang memberikan gerakan dalam jangkauan pandangan dibandingkan obyek yang diam. 
Menurut Garvin dalam Yamit (2001:10), mengungkapkan ada delapan dimensi persepsi, yaitu:

1. Dimensi Kinerja Produk (Performance), yaitu karakteristik pokok dari produk inti. Apakah kualitas produk menggambarkan keadaan yang sebenarnya.

2. Dimensi Keterandalan Produk (Reliability), yaitu kemungkinan tingkat kegagalan pemakaian.

3. Dimensi Fitur Produk (Feature), yaitu karakteristik pelengkap atau tambahan.

4. Dimensi Daya Tahan (Durability), yaitu berapa lama produk itu dapat terus digunakan.

5. Dimensi Kesesuaian (Comformance), yaitu sejauh mana karakteristik desain dan operasi memenuhi standar-standar yang telah ditetapkan sebelumnya.

6. Dimensi Kemampuan Diperbaiki (Servicebility), yaitu meliputi kecepatan, kompetensi, kenyamanan, kemudahan dalam pemeliharaan dan penanganan keluhan yang memuaskan.

7. Dimensi Keindahan Tampilan Produk (Aesthetic), yaitu menyangkut corak, rasa, dan daya tarik produk.

8. Dimensi Kualitas yang Dirasakan (Perceived Quality), yaitu menyangkut citra dan reputasi produk serta tanggung jawab perusahaan terhadapnya.

\section{HIPOTESIS PENELITIAN}

Berdasarkan kerangaka teoritis diatas maka hipotesis yang diteliti sebagai berikut:

1. Pengaruh Niat seseorang mahasiswa dalam pengambilan sertifikat CA

2. Pengaruh Motivasi diri mahasisawa untuk mengambil sertifikat CA

3. Pengaruh Persepsi mahasiswa terhadap pengambilan sertifikat CA

4. Pengaruh Penghargaan Finansial terhadap niat pengambilan sertifikasi CA

\section{HASIL PENELITIAN DAN PEMBAHASAN}

Hasil pengumpulan data melalui pengumpulan jawaban responden akan diolah untuk memperoleh gambaran objek dari variabel-variabel untuk penelitian. Pengukuran variabel dalam penelitian ini menggunakan kuisoner untuk menentukan rata-rata dari masing-masing responden tersebut dan akan diolah untuk memperoleh gambaran obyek dari variabel-variabel yang digunakan dalam penelitian.

Dalam penelitian ini responden yang dipilih adalah mahasiswa Program studi Akuntansi di Adi Buana Surabaya. Akuntansi adalah salah satu prodi yang paling banyak peminat dalam perguruan tinggi, oleh sebab itu peneliti akan meneliti tentang niata mahasiswa dalam pengambilan sertifikasi akuntan. Dimana jumlah mahasiswa prodi akuntansi angkatan 2020 di Adi Buana Surabaya berjumlah 205 mahasiswa.

Penelitian ini merupakan penelitian kuantitatif dengan pendekatan survey dan pengambilan datanya menggunakan kuesioner. Kuesioner disebar sebanyak 10 secara langsung melalui google form dan kuesioner yang kembali sebanyak 10, serta seluruh kuesioner dapat diolah sebagai berikut dengan hasil dari pengumpulan data terhadap responden dalam penelitian ini yaitu mahasiswa prodi akuntansi S1 Akuntansi Adi Buana Surabaya yang terdaftar aktif pada semester genap tahun ajaran 2020/2021 dengan jumlah 
responden sebanyak 10 mahasiswa. Kuesioner sejumlah 10 buah diberikan kepada responden melalui kuesioner online melalui google form sebanyak 10 kuesioner yang telah diisi secara lengkap dan benar sehingga dapat di analisis lebih lanjut.

Pada analisis statistik deskriptif digunakan sebagai gambaran keadaan variabelvariabel penelitian secara statistik. Penelitian ini menggunakan nilai rata-rata (mean), nilai maksimum, nilai minimum, dan standar deviasi untuk menggambarkan suatu deskripsi statistik. Sehingga Penilaian terhadap variable dapat diukur menggunakan 46 skala interval 14 dengan skor terendah yakni 1 (sangat rendah) dan skor tertinggi 4 (sangat tinggi).

Tabel 1

Statistik Deskriptif Variabel

\begin{tabular}{|c|c|c|c|c|c|}
\hline Indikator Variabel & $\mathrm{N}$ & Minimum & Maximum & Mean & $\begin{array}{c}\text { Std. } \\
\text { Devation }\end{array}$ \\
\hline Niat & 10 & 1.00 & 4.00 & 2.8456 & 0,49508 \\
\hline Motivasi & 10 & 1.00 & 4.00 & 2.9611 & 0,57928 \\
\hline Persepsi & 10 & 1.00 & 4.00 & 2.8007 & 0,56944 \\
\hline Penghargaan Finansial & 10 & 1.00 & 4.00 & 3.0670 & 0,47210 \\
\hline CA & 10 & 1.00 & 4.00 & 2.9794 & 0,55985 \\
\hline
\end{tabular}

Berdasarkan hasil analisis deskriptif variabel maka:

1. Niat memiliki nilai minimum sebesar 1 dan nilai maksimum sebesar 4 yang berarti bahwa nilai penilaian terendah 1 dan nilai tertingginya 4 dengan nilai rata-rata sebesar 2.8456 . Standart devisanya sebesar 0.49508 dari 10 responden.

2. Motivasi memiliki nilai minimum 1 dan nilai maksimum 4 yang berarti bahwa nilai terendah dari motivasi sebesar 1 dan nilai tertingginya sebesar 4 dengan nilai rataratannya sebesar 2.9611. Standart devisanya sebesar 0.57928 dari 10 responden.

3. Persepsi memiliki nilai minimum 1 dan nilai maksimumnya 4 yang berarti bahwa nilai terendah dari persepsi sebesar 1 dan nilai tertingginya sebesar 4 dengan nilai rata-ratannya sebesar 2.8007. Standart devisanya sebesar 0.56944 dari 10 responden.

4. Penghargaan Finansial memiliki nilai minimum 1 dan nilai maksimumnya 4 yang berarti bahwa nilai terendah dari presepsi sebesar 1 dan nilai tertingginya sebesar 4 dengan nilai rata-ratannya sebesar 3.0670. Standart devisanya sebesar 0.427210 dari 10 responden

5. CA memiliki nilai minimum 1 dan nilai maksimumnya 4 yang berarti bahwa nilai terendah dari presepsi sebesar 1 dan nilai tertingginya sebesar 4 dengan nilai rataratannya sebesar 2.9794. Standart devisanya sebesar 0.55985 dari 10 responden. 


\section{KESIMPULAN}

1. Motivasi pada sertifikasi akuntan berpengaruh terhadap niat mahasiswa untuk mengambil sertifikat akuntan. Semakin tinggi motivasi maka akan semakin tinggi niat untuk mengambil sertifikasi akuntan.

2. Persepsi mahasiswa yang akan mengambil sertifikasi akuntan berpengaruh terhadap mahasiswa untuk mengambil sertifikasi akuntan. Semakin baik presepsi mahasiswa yang akan mengambil sertifikasi akuntan maka akan semakin tingggi niat mahasiswa untuk mengambil sertifikasi akuntan.

3. Penghargaan Finansial pada sertifikasi akuntan tidak berpengaruh terhadap niat mahasiswa untuk menggambil sertifikasi akuntan.

\section{SARAN}

1. Diharapkan pada pihak penyelenggara pihak AC gencar melakukan sosialisai, tidak hanya sosialisai dalam seminar tetapi sosialisasi per kelas, agar mahasiwa banyak yang tahu dan nantinya tertarik dengan sertifikasi AC. Dan sebaiknya AC menyiapkan pelatihan yang kompeten di AC ini.

2. Motivasi dan presepsi tentang sertifikasi akuntan perlu ditingkatkan dan diperbaiki, diberikan dan diberikan pengetahuan tentang sertifikasi akuntan yang ada.

\section{DAFTAR PUSTAKA}

Adisti, Atsari.2014. " Analisis Faktor-Faktor Yang Mempengaruhi Minat Mahasiswa Akuntansi Memilih Berkarir Sebagai Akuntan

Publik."https://dspace.uii.ac.id/bitstream/handle/123456789/12259/SKRIPSI\%20ADISTI\%2 0ASTASARI\%20AKUNTAN\%20PUBLIK 14312139.pdf? sequence=1\&isAllowed=y

Agung Gita Subakti, Darwin Tenironama, Ari Yuniarso Bina Nusantara University.2018. “ Analisis Persepsi Akuntan." file:///C:/Users/ASUS/Downloads/11687-24431-1-SM.pdf

Akbar Iman Pradana, Dwi Cahyono, Astrid Maharani.2015. "Faktor-Faktor Yang Mempengaruhi Niat Pengambilan Sertifikasi Akuntan."

https://sg.docworkspace.com/d/sIIGVpc4w-uGzjQY

Amalia, Nur, Dianati.2017. ''Faktor-Faktor Yang Mempengaruhi Minat Mahasiswa Akuntansi Stie Perbanas Surabaya Dalam Pemilihan Karir Sebagai Akuntan Publik.', http://eprints.perbanas.ac.id/2596/1/ARTIKEL\%20ILMIAH.pdf

Ben, Fauzi, Ramadhan.2009. “http://lib.ui.ac.id/file?file=digital/125416-S-5609-

Gambaran\%20persepi-Literatur.pdf

Insitut of indonesia accountants. "Ikatan Akuntansi

Indonesia.”http://iaiglobal.or.id/v03/CA/menjadi-CA

Jumiati.2018. "Faktor - Faktor Yang Memengaruhi Minat Mahasiswa Akuntansi Dalam Pemilihan Karir Sebagai Akuntan Publik Dengan Financial Reward Sebagai Variabel Moderasi.".http://repositori.uin-alauddin.ac.id/17002/1/FAKTOR\%20\%20FAKTOR\%20\%20YANG\%20MEMENGARUHI\%20MINAT\%20MAHASISWA.pdf 
Livia, Della, Ramadhanty. "Pengaruh Literasi Keuangan"

http://repository.unair.ac.id/101621/5/5.\%20BAB\%202\%20TINJAUAN\%20PUSTAKA\%20. pdf

Niko, Ardianto.2014. "Faktor-Faktor Yang Mempengaruhi Minat Mahasiswa Akuntansi Terhadap Pemilihan Karir Akuntan Atau Non Akuntan."

http://eprints.undip.ac.id/43982/1/16_ARDIANTO.pdf

Om.makplus.2016.“Pengertian Motivasi serta Definisi Menurut Ahli”. http://www.definisipengertian.com/2016/01/pengertian-motivasi-definisi-menurut-ahli.html

Shabrina, Dyah, Permatasari.2018. “Faktor - Faktor Yang Mempengaruhi Niat Mahasiswa Akuntansi Untuk Mengikuti Ujian Sertifikasi Acca.

https://sg.docworkspace.com/d/sIKOVpc4wyeKzjQY 